\title{
PENGEMBANGAN MINAT BELAJAR DALAM PEMBELAJARAN
}

\author{
ANDI ACHRU P. \\ Fakultas Tarbiyah dan Keguruan UIN Alauddin Makassar \\ Jl. HM. Yasin Limpo No. 36 Makassar \\ Email: andiachruh@gmail.com
}

\begin{abstract}
:
Interest in learning is a driving force from within individuals to conduct learning activities to increase knowledge and skills and experience. This interest grows because of the desire to know and understand something that encourages and directs students' interest in learning so that they are sincere in their learning. Interest in learning is the tendency of students to conduct learning activities that are driven by a desire to achieve the best possible learning outcomes. Based on the definitions from the experts it can be concluded that the interest in learning is the energy that drives a person to achieve learning goals. Interest in learning does not only depend on ability, but also depends on whether someone chooses mastery goals (learning objectives), the focus of which is to learn a new ability well; or performance goals, the focus of which is to demonstrate or show our abilities to others.
\end{abstract}

Keywords: Development, Learning Interest, Learning

\section{PENDAHULUAN}

endidik sering terdengar bahwa mendidik murid yang berprestasi tinggi jauh lebih mudah ketimbang mendidik murid berprestasi rendah. Benarkah ungkapan tersebut? Tentu para pendidik sendiri lebih tahu jawabannya. Persoalannya, bagaimana memaksimalkan potensi yang beraneka ragam tersebut (terutama murid yang berprestasi rendah) sehingga bisa menciptakan iklim belajar yang kondusif yang akhirnya membuahkan sumber daya manusia yang unggul. Untuk mencapai harapan tersebut faktor kualitas dan karakter pada pendidikpun tentu turut menentukan, selain harus di tunjang sarana dan prasarana serta lingkungan yang memadai. Karena itulah pendidikan remedial sebagai sarana pengembangan mutu sumber daya manusia dalam kegiatan belajar mengajar.

Mayoritas di lembaga pendidikan masih banyak yang kurang tepat dalam melaksanakan pembelajaran remidi. Prakteknya bisa dikatakan mengulang lagi soal yang semula belum tuntas dan itu biasa dinamakan HER. Remedial bukan HER, melainkan perbaikan nilai bagi peserta didik yang belum tuntas belajarnya sesuai dengan nilai ketuntasan minimal atau Kriteria Ketuntasan Minimal (KKM), dengan menggunakan strategi baru, atau menugaskan kepada peserta didik yang pada akhirnya bisa menjawab soal yang belum tuntas. Inilah praktek remidi yang sesungguhnya.

Belajar merupakan suatu proses usaha yang dilakukan seseorang untuk memperoleh suatu perubahan tingkah laku yang baru secara keseluruhan, 
sebagai hasil pengalamannya sendiri dalam interaksi dengan lingkungannya (Slameto, 2003: 2).

Ini berarti bahwa berhasil tidaknya pencapaian tujuan pendidikan banyak bergantung kepada bagaimana proses belajar yang dialami oleh peserta didik sebagai anak didik. Namun kenyataannya, di beberapa sekolah sering ditemui sejumlah peserta didik yang memperoleh hasil belajar jauh dibawah rata-rata yang telah ditetapkan.

Seorang pendidik harus mengetahui keberadaan anak didiknya dalam menangkap dan memperhatikan pada saat berlangsungnya proses pembelajaran di dalam kelas, untuk itu di samping menguasai materi juga dibutuhkan pemahaman karakteristik anak didik. Karena sesungguhnya, setiap peserta didik dalam mencapai sukses belajar mempunyai kemampuan yang berbeda-beda. Ada peserta didik yang dapat mencapainya tanpa kesulitan, akan tetapi banyak pula peserta didik mengalami kesulitan. Peserta didik sulit meraih hasil belajar yang baik di sekolah, padahal telah mengikuti pelajaran dengan sungguh-sungguh. Bahkan juga ada peserta didik yang menambah belajar tambahan di rumah, tapi hasilnya tetap masih kurang memuaskan. Maka, pendidik harus berperan turut membantu memecahkan masalah yang dihadapi peserta didik. Pendidik bertanggung jawab membantu peserta didik agar dapat mencapai tujuan pembelajaran, sehingga bisa memberikan kesempatan kepada mereka untuk meningkatkan hasil belajarnya.

Kesulitan belajar merupakan masalah yang perlu ditanggulangi secara cermat. Pengulangan kesulitan belajar yang tidak tuntas menjadikan penghalang dalam perkembangan anak selanjutnya. Berbagai teknik dan bentuk penanggulangan kesulitan perlu diterapkan dengan pertimbangan yang mendasar (Jamaris, 2014: 61). Untuk itu, jika ada anak didik yang hasil belajarnya kurang bagus, maka pendidik harus memberikan waktu untuk anak didik tersebut, misalnya dengan memberikan pengajaran remedial dan pendekatan-pendekatan yang tentunya dapat memotivasi agar anak didik lebih giat dalam belajar.

\section{HASIL PENELITIAN DAN PEMBAHASAN}

\section{Pengertian Minat Belajar}

Minat diartikan sebagai "kecenderungan hati yang tinggi terhadap sesuatu, gairah, keinginan" sedangkan "berminat" diartikan mempunyai (menaruh) minat, kecenderungan hati kepada, ingin (akan) (Depdiknas, 2013: 1152). Dalam Kamus Besar Bahasa Indonesia adalah kecenderungan hati yang tinggi terhadap sesuatu; gairah, keinginan (Depdiknas, 2013: 656). Sedang minat menurut Mahfudz Shalahuddin adalah perhatian yang mengandung unsur-unsur perasaan, Sementara itu menurut Soeganda Poerbakawatja dan Harahap, minat diartikan kesediaan jiwa yangt sifatnya aktif untuk menerima sesuatu dari luar (Poerbakawatja dan Harahap, 2012: 214). 
The Liang Gie (2014: 28) memberikan Pengertian yang paling mendasar tentang minat" minat artinya sibuk, tertarik, atau terlibat dengan sesuatu kegiatan karena menyadari pentingnya kegiatan itu. Selain itu Agus Sujanto (2013: 92) memberikan Pengertian tentang minat "sesuatu pemusatan perhatian yang tidak disengaja yang terlahir dengan kemauannya dan yang tergantung dari bakat dan lingkungannya.

Beberapa pengertian minat yang dikemukakan oleh para ahli di atas, maka dapat diasumsikan bahwa minat adalah suatu pemusatan perhatian yang mengandung unsur-unsur perasaan, kesenangan, kecenderungan hati, keinginan yang tidak disengaja yang sifatnya aktif untuk menerima sesuatu dari luar (lingkungan).

Minat adalah sesuatu yang sangat penting bagi seseorang untuk melakukan suatu aktivitas. Dengan minat orang akan berusaha mencapai tujuannya. Oleh karena itu minat dikatakan sebagai salah satu aspek psikis manusia yang dapat mendorong untuk mencapai tujuan.

Ada dua aspek yang dikandung oleh minat antara lain aspek kognitif dan aspek afektif. Aspek kognitif mengandung pengertian bahwa minat selalu didahului oleh pengetahuan, pengetahuan, pemahaman dan konsep yang diperoleh dan dikembangkan dan pengalaman atau hasil interaksi dengan lingkungannya. Aspek afektif menunjukkan pada derajat emosional yang dinyatakan dalam bentuk proses menilai untuk menentukan kegiatan yang disenangi. Jadi, suatu aktivitas bila disertai dengan minat individu yang kuat, maka ia akan mencurahkan perhatiannya dengan baik terhadap aktivitas tersebut. Aspek minat manusia dalam mengikuti pembelajaran fikih sangat kuat, maka akan merupakan dasar pula untuk menciptakan situasi pembelajaran yang kondusif, yang dapat memenuhi keinginan siswa untuk belajar disertai perhatian yang besar.

Istilah minat banyak dipakai dalam berbagai bidang dan situasi, tapi dalam uraian ini akan lebih diarahkan pada bidang pendidikan khususnya dalam bidang pembelajaran (Depdiknas, 2013: 756). Minat adalah proses perkembangan dan pengarahan perilaku atau kelompok, agar individu atau kelompok itu menghasilkan keluaran yang diharapkan, sesuai sasaran yang ingin dicapai organisasi (Sumanto, 2014: 168). Minat merupakan istilah yang lebih umum yang merujuk pada seluruh proses gerakan, termasuk situasi yang mendorong, dorongan yang timbul dalam diri individu, tingkah laku yang ditimbulkannya, dan tujuan atau akhir dari gerakan atau perbuatan (Sobur, 2013: 268). Minat adalah kondisi fisiologis dan psikologis yang terdapat dalam diri seseorang yang mendorong untuk melakukan aktivitas tertentu guna mencapai suat tujuan (kebutuhan) (Djaali, 2013: 101).

Menurut Santrock (2012: 135), minat adalah proses yang memberi semangat, arah, dan kegigihan perilaku. Artinya, perilaku yang memiliki motivasi adalah perilaku yang penuh energi, terarah, dan bertahan lama. Dalam kegiatan belajar, maka motivasi dapat dikatakan sebagai keseluruhan daya penggerak di 
dalam diri peserta didik yang menimbulkan kegiatan belajar, yang menjamin kelangsungan dari kegiatan belajar dan memberikan arah pada kegiatan belajar, sehingga tujuan yang dikehendaki oleh subjek belajar itu dapat tercapai.

Minat belajar adalah daya penggerak dari dalam diri individu untuk melakukan kegiatan belajar untuk menambah pengetahuan dan keterampilan serta pengalaman. Minat ini tumbuh karena adanya keinginan untuk mengetahui dan memahami sesuatu mendorong serta mengarahkan minat belajar peserta didik sehingga lebih sungguh-sungguh dalam belajarnya (Iskandar, 2012: 181). Minat belajar menurut Clayton Aldelfer dalam Nashar adalah kecenderungan peserta didik dalam melakukan kegiatan belajar yang didorong oleh hasrat untuk mencapai prestasi hasil belajar sebaik mungkin (Nashar, 2014: 42). Berdasarkan defInisi dari para ahli dapat disimpulkan bahwa minat belajar adalah energi kekuatan yang mendorong seseorang untuk mencapai tujuan belajar.

Minat belajar tidak hanya bergantung pada kemampuan, namun juga bergantung pada apakah seseorang memilih tujuan penguasaan (tujuan mempelajari), yang fokusnya adalah mempelajari suatu kemampuan baru dengan baik; atau tujuan kinerja, yang fokusnya adalah mendemonstrasikan atau memperlihatkan kemampuan kita pada orang lain. Dengan demikian orang yang memiliki kebutuhan prestasi yang tinggi berbeda dari orang lain dalam cara berikut:

1. Mereka mencari tanggung jawab pribadi untuk mencari solusi dari permasalahan. Ini berarti mereka mengambil inisiatif untuk menemukan hasil, kadang-kadang bahkan ketika itu bukanlah masalah mereka.

2. Mereka membutuhkan umpan balik yang cepat pada kinerja mereka. Mereka biasanya sangat frustasi ketika tidak menerima umpan balik, dan lebih cepat lebih baik.

3. Mereka menetapkan tujuan tepat yang menantang. Mereka dengan semangat tinggi ingin mengontrol kesuksesan mereka sendiri, mereka tidak ingin meraih sesuatu atau apa pun secara kebetulan.

4. Mereka ingin mengembangkan diri, sehingga mereka menetapkan tujuan yang menantang tapi yang mereka anggap memiliki setidaknya kesempatan 50\% untk dicapai (Intan, 2014: 40-41).

Terdapat banyak pandangan dan pembahasan dari banyak ahli di bidang psikologi pendidikan maupun psikologi pembelajaran terkait dengan motivasi, banyaknya pandangan dan pembahasan menghasilkan definisi yang banyak pula, tetapi pada intinya motivasi ialah dorongan yang berasal dari dalam diri seseorang ataupun di luar diri seseorang, baik disadari ataupun tidak untuk melakukan suatu tindakan.

Mc. Donald (dalam Djamarah, 2012: 114) mengatakan bahwa, minat adalah suatu perubahan energi di dalam pribadi seseorang yang ditandai dengan timbulnya afektif (perasaan) dan reaksi untuk mencapai tujuan. Minat ialah 
keadaan internal organisme baik manusia ataupun hewan yang mendorongnya untuk berbuat sesuatu (Syah, 2013: 134).

Abraham Maslow (Uno, 2014: 41) mengatakan seseorang termotivasi karena memiliki kebutuhan yang harus dipenuhi. Kebutuhan yang dimaksud menurut Maslow yaitu:

\section{Kebutuhan Fisiologis}

Kebutuhan Fisiologis yaitu kebutuhan dasar yang harus dipenuhi sebelum kebutuhan-kebutuhan lain terpenuhi. Yang termasuk dalam kebutuhan jenis ini adalah makanan, rumah, pakaian, udara, dan sebagainya.

\section{Kebutuhan akan Rasa Aman}

Kebutuhan rasa aman ini termasuk kebutuhan akan keselamatan dari ancaman fisik atau kehilangan, serta merasa terjamin. Kebutuhan akan rasa aman merupakan kebutuhan yang dipenuhi setelah kebutuhan fisiologis terpenuhi.

\section{Kebutuhan akan Cinta Kasih/Kebutuhan Sosial}

Yaitu kebutuhan akan cinta kasih seperti rasa diterima oleh kelompok, perasaan dihargai dan dihormati oleh orang lain.

\section{Kebutuhan akan Penghargaan}

Manusia setelah melakukan pekerjaan atau tugas, maka manusia cenderung untuk mendapatkan penghargaan dan ingin mendapatkan peengakuan dari oran lain.

\section{Kebutuhan Aktualisasi Diri}

Kebutuhan aktualisasi diri merupakan kebutuhan berprestasi yang erat kaitannya dengan kebutuhan untuk mengembangkan bakat dan minat yang dimiikinya. Kebutuhan aktualisasi diri sering juga disebut dengan kebutuhan untuk menjadi dirinya sendiri.

Pada hakikatnya minat belajar adalah dorongan internal dan eksternal pada peserta didik yang sedang belajar untuk mengadakan perubahan tingkah laku (Uno, 2014: 23). Contoh, peserta didik yang termotivasi karena ingin berprestasi pada setiap mata pelajaran yang dia tempuh, selalu berusaha membaca buku dimalam hari pada mata pelajaraan yang akan diajarkan oleh pendidik. Jadi kebutuhan yang ingin dia penuhi adalah berprestasi. Itulah contoh motivasi yang berasal dari dalam diri. Contoh kedua, peserta didik yang termotivasi untuk belajar karena mendapat janji dari pendidik untuk mendapat hadiah, maka dia bersemangat untuk belajar. Itulah contoh motivasi yang berasal dari luar (Asrori, 2012: 183).

Berdasarkan penjelasan di atas dapat dipahami bahwa minat merupakan berbagai usaha yang dilakukan sehingga seseorang melakukan sesuatu. Bila dihubungkan dengan proses belajar, maka minat dapat diartikan sebagai keseluruhan daya penggerak untuk melakukan kegiatan belajar.

Minat adalah hal dan keadaan yang berasal dari dalam diri peserta didik sendiri yang dapat mendorongnya melakukan tindakan belajar. Termasuk dalam 
minat peserta didik adalah perasaan menyenangi materi dan kebutuhannya terhadap materi tersebut, misalnya untuk kehidupan masa depan peserta didik yang bersangkutan (Syah, 2013: 134). Minat adalah motif-motif yang menjadi aktif atau berfungsinya tidak perlu dirangsang dari luar karena dalam diri setiap individu sudah ada dorongan untuk melakukan sesuatu. Sebagai contoh seseorang yang senang membaca tidak usah ada yang menyuruh atau mendorongnya karena ia sudah rajin mencari buku-buku untuk dibacanya.

\section{Unsur-Unsur Minat Belajar}

Perhatian sangatlah penting dalam mengikuti kegiatan dengan baik, dan hal ini akan berpengaruh pula terhadap minat peserta didik dalam belajar. Menurut Sumadi Suryabrata (2012: 14) "perhatian adalah banyak sedikitnya kesadaran yang menyertai aktivitas yang dilakukan. Kemudian Wasti Sumanto (2014: 32) berpendapat "perhatian adalah pemusatan tenaga dan kekuatan jiwa tertentu kepada suatu obyek, atau pendayagunaan kesadaran untuk menyertai suatu aktivitas".

Aktivitas yang disertai dengan perhatian intensif akan lebih sukses dan prestasinyapun akan lebih tinggi. Sebagai seorang guru harus selalu berusaha untuk menarik perhatian peserta didik sehingga mereka mempunyai minat terhadap pelajaran yang diajarkan.

Orang yang memiliki minat pada suatu aktivitas akan memberikan perhatian yang besar. Tidak segan mengorbankan waktu dan tenaga demi aktivitas tersebut.

Unsur yang tak kalah pentingnya adalah perasaan dari peserta didik terhadap pelajaran yang diajarkan oleh gurunya. Perasaan didefinisikan "sebagai gejala psikis yang bersifat subjektif yang umumnya berhubungan dengan gejala-gejala mengenal dan dialami dalam kualitas senang atau tidak dalam berbagai taraf (Suryabrata, 2012: 66).

Tiap aktivitas dan pengalaman yang dilakukan akan selalu diliputi oleh suatu perasaan, baik perasaan senang maupun perasaan tidak senang. Perasaan umunya berkaitan dengan fungsi mengenal artinya perasaan dapat timbul karena mengamati, menganggap, mengingat-ingat atau memikirkan sesuatu, yang dimaksud dengan perasaan disini perasaan senang dan perasaan tertarik. "Perasaan merupakan aktivitas psikis yang didalamnya subyek menghayati nilainilai suatu objek (Winkel, 2013: 30). Perasaan sebagai faktor psikis non intelektual, yang khusus berpengaruh terhadap minat belajar. Jika seorang peserta didik melakukan penilaian melalui perasaannya tentang pengalaman belajar disekolah, dan penilaian itu menghasilkan penilaian yang positif maka akan timbul perasaan senang dihatinya akan tetapi jika penilaiannya negatif maka timbul perasaan tidak senang.

Perasaan senang akan menimbulkan minat, yang diperkuat dengan sikap positif. Sedangkan perasaan senang akan menghabat dalam mengajar, karena tidak adanya sikap yang positif sehingga tidak menunjang minat dalam belajar. 
Minat muncul karena motivasi sehingga, motivasi diartikan sebagai daya upaya yang mendorong seseorang untuk melakukan sesuatu. Motivasi dapat dikatakan "sebagai daya penggerak dari dalam dan di dalam subyek untuk melakukan kreativitas tertentu demi mencapai suatu tujuan (Sardiman 2015: 73). Peserta didik melakukan aktivitas belajar karena ada yang mendorongnya. Dalam hal ini motivasi sebagai dasar penggeraknya yang mendorong peserta didik untuk belajar. Dan minat merupakan potensi psikologi yang dapat dimanfaatkan untuk menggali motivasi, bila peserta didik sudah termotivasi untuk belajar, maka dia akan melakukan aktivitas belajar dengan baik. Tidak adanya minat terhadap suatu pelajaran menjadi penyebab peserta didik tidak memperhatikan pelajaran yang disampaikan oleh guru. Oleh karena itu guru harus membangkitkan minat peserta didik. Sehingga peserta didik yang tidak berminat menjadi berminat untuk belajar.

Motivasi merupakan dasar penggerak yang mendorong aktivitas belajar peserta didik sehingga peserta didik berminat terhadap sesuatu objek, karena minat adalah motivasi dalam belajar.

Adapun indikator untuk menentukan minat belajar seseorang dapat dilihat pada lima aspek yaitu: (1) Rajin dalam belajar, (2) Tekun dalam belajar, (3) Rajin dalam mengerjakan tugas, (4) Memiliki jadwal belajar, dan (5) Disiplin dalam belajar (aniendriani.blog.spot.com. diakses pada tanggal 10 Juni 2017).

\section{Faktor-Faktor yang Mempengaruhi Minat Belajar}

Apabila kita memperhatikan tentang faktor-faktor yang mempengaruhi minat belajar terhadap mata pelajaran tertentu, termasuk dalam mata pelajaran fikih, secara keseluruhan faktor tersebut digolongkan dalam dua kelompok besar, yaitu faktor eksternal (faktor yang berasal dari luar diri siswa) dan faktor internal (faktor yang berasal dari dalam diri peserta didik). Dari beberapa faktor yang dapat mempengaruhi minat siswa dalam mata pelajaran fikih, dapat dilihat pada faktor kurikulum, faktor dari dalam diri siswa, faktor metode mengajar, faktor guru, serta sarana dan prasarana, termasuk penggunaan multimedia pembelajaran.

Beberapa faktor yang mempengaruhi minat belajar siswa, menurut Totok Susanto, sebagai berikut:

1. Memotivasi dan cita-cita

2. Keluarga

3. Peranan guru

4. Sarana dan prasarana

5. Teman pergaulan

6. Mass media (Sardiman 2015: 74).

Belajar merupakan suatu perubahan yang terjadi melalui latihan atau pengalaman (Purwanto, 2014: 85). Dalam proses pembelajaran, unsur kegiatan belajar memegang peranan yang vital. Oleh karena itu, penting sekali bagi setiap guru memahami sebaik-baiknya tentang proses belajar peserta didik agar dapat memberikan bimbingan dan menyediakan lingkungan belajar yang tepat dan serasi 
bagi peserta didik. Kaitannya dengan minat, guru dalam pembelajaran terutama pada mata pelajaran Fikih harus bisa memberikan suatu inovatif yang baru untuk menarik minat peserta didik, agar proses pembelajaran berjalan sesuai dengan tujuan.

Minat merupakan salah satu faktor yang dapat mempengaruhi usaha yang dilakukan seseorang. Minat yang kuat akan menimbulakan usaha serius dan tidak mudah putus asa dalam menghadapi tantangan. Peserta didik yang memiliki keinginan belajar, maka peserta diik cepat dan dapat mengerti dan mengingatnya.

Dalam hubungannya dengan pemusatan perhatian, minat mempunyai peranan dalam "melahirkan perhatian yang serta merta, memudahkan terciptanya pemusatan perhatian, dan mencegah gangguan perhatian dari luar (Suryabrata, 2012: 57).

Minat mempunyai pengaruh yang besar dalam belajar karena bahan pelajaran yang dipelajari tidak sesuai dengan minat peserta didik maka peserta didik tidak akan belajar dengan sebaik-baiknya, sebab tidak ada daya tarik baginya. Sebaliknya bila bahan pelajaran menarik minat peserta didik, maka pelajaran mudah dipelajari dan diingat karena adanya minat sehingga menambah minat dalam kegiatan belajar mengajar.

Fungsi minat dalam belajar lebih besar sebagai kekuatan yang mendorong peserta didik untuk belajar. Peserta didik yang berminat pada pelajaran akan terdorong terus untuk tekun belajar, berbeda dengan peserta didik yang sikapnya hanya menerima pelajaran, mereka hanya tergerak untuk mau belajar tetapi sulit untuk tekun karena tidak ada pendorongnya. Untuk memperoleh hasil yang baik dalam belajar peserta didik harus mempunyai minat terhadap pelajaran sehingga mendorong peserta didik tersebut untuk terus belajar.

Minat berfungsi sebagai pendorong keinginan seseorang, penguat hasrat dan sebagai penggerak dalam berbuat yang berasal dari dalam diri seseorang untuk melakukan suatu dengan tujuan dan arah tingkah laku sehari-hari. Hal ini diterangkan oleh Sardiman (2013: 84) yang menyatakan berbagai fungsi minat, sebagai berikut:

1. Mendorong manusia untuk berbuat, yaitu sebagai penggerak atau motor yang melepaskan energi.

2. Menentukan arah perbuatan, yakni ke arah tujuan yang hendak dicapai.

3. Menyeleksi perbuatan, yakni menentukan perbuatan-perbuatan apa yang serasi guna mencapai tujuan.

Fungsi minat dalam kaitannya dengan pelaksanaan studi adalah:

1. Minat melahirkan perhatian yang serta merta

2. Minat memudahkan tercapainya konsentrasi.

3. Minat mencegah gangguan perhatian dari luar

4. Minat memperkuat pelekatnya bahan pelajaran dalam ingatan

5. Minat memperkecil kebosanan studi dalam diri sendiri (Gie, 2014: 29). 
Adapun istilah belajar menurut bahasa adalah "usaha (berlatih) dan sebagai upaya mendapatkan kepandaian" (Poerwadarminta, 1976: 965). Sedangkan menurut istilah yang dipaparkan oleh beberapa ahli, diantaranya oleh Ahmad Fauzi (2014: 44) yang mengemukakan belajar adalah "suatu proses dimana suatu tingkah laku ditimbulkan atau diperbaiki melalui serentetan reaksi atas situasi (rangsangan) yang terjadi".

Kemudian Slameto (2013: 57) mengemukakan pendapat Gronback yang mengatakan "Learning is show by a behavior as a result of experience". Selanjutnya Moh. Uzer Usman dan Lilis Setiawati (2012: 4) mengartikan "belajar sebagai perubahan tingkah laku pada diri individu berkat adanya interaksi antara individu dengan individu dan individu dengan lingkungan sehingga mereka lebih mampu berinteraksi dengan lingkungannya".

Nana Sudjana (1987: 28) mengatakan "belajar adalah proses yang aktif, belajar adalah mereaksi terhadap semua situasi yang ada di sekitar individu. Belajar adalah proses yang diarahkan kepada tujuan kepada tujuan, proses berbuat melalui berbagai pengalaman. Belajar adalah proses melihat, mengamati, memahami sesuatu.

Sardiman (2004: 2) mengatakan belajar adalah usaha mengubah tingkah laku. Arthur J. Gates dalam Fudyartanto menjelaskan bahawa belajar adalah perubahan tingkah laku melalui pengalaman dan latihan, selanjutnya Hamalik belajar adalah modifikasi atau mempengaruhi kelakuan melalui pengalaman (Hamalik, 2013: 36). Menurut pengertian ini belajar adalah merupakan suatu proses kegiatan dan bukan suatu hasil atau tujuan. Belajar bukan saja mengingat, akan tetapi lebih luas daripada itu, yakni mengalami. Hasil belajar bukan suatu penguasaan hasil latihan melainkan perbaikan kelakuan pengertian belajar yang telah dikemukakan oleh para ahli tersebut di atas, disimpulkan bahwa belajar adalah suatu perubahan tingkah laku individu dari hasil pengalaman dan latihan. Perubahan tingkah laku tersebut, baik dalam aspek pengetahuannya (Kognitif), keterampilan (psikomotor), maupun sikapnya (afektif).

Dari pengertian minat dan pengertian belajar seperti yang telah diuraikan di atas, maka dapat disimpulkan bahwa minat belajar adalah sesuatu keinginan atau kemauan yang disertai perhatian dan keaktifan yang disengaja yang akhirnya melahirkan rasa senang dalam perubahan tingkah laku, baik berupa pengetahua, sikap dan keterampilan.

\section{PENUTUP/SIMPULAN}

Berdasarkan pembahasan sebelumnya, maka disimpulkan hal-hal sebagai berikut:

1. Minat adalah suatu pemusatan perhatian yang mengandung unsur-unsur perasaan, kesenangan, kecenderungan hati, keinginan yang tidak disengaja yang sifatnya aktif untuk menerima sesuatu dari luar (lingkungan). Bila 
ANDI ACHRU P.

dihubungkan dengan proses belajar, maka minat dapat diartikan sebagai keseluruhan daya penggerak untuk melakukan kegiatan belajar.

2. Beberapa hal yang termasuk dalam unsur minat belajar adalah; perhatian, perasaan senang, dan motivasi. Adapun indikator untuk menentukan minat belajar seseorang dapat dilihat pada lima aspek yaitu: (1) rajin dalam belajar, (2) tekun dalam belajar, (3) rajin dalam mengerjakan tugas, (4) memiliki jadwal belajar, dan (5) disiplin dalam belajar.

3. Faktor-faktor yang mempengaruhi minat belajar yaitu; faktor kurikulum, faktor dari dalam diri siswa, faktor metode mengajar, faktor guru, serta sarana dan prasarana, termasuk penggunaan multimedia pembelajaran. Faktor lain yang mempengaruhi adalah; motivasi dan cita-cita, keluarga, peranan guru, sarana dan prasarana, teman pergaulan, dan mass media.

\section{DAFTAR PUSTAKA}

Asrori, Muhammad (2012), Psikologi Pembelajaran, Cet.l; Bandung: CV. Wacana Prima.

Braden, P. A. McClelland's (2000), Theory of Needs (WVUP. Parkersburg: West Virginia University), dikutip dalam Besse Intan, "Pengaruh Pola Asuh Orang Tua, Gaya Belajar, dan Motivasi Berprestasi terhadap Prestasi Belajar Matematika Peserta didik MTs Se-Makassar", Laporan Hasil Penelitian, Makassar: Pascasarjana UNM, 2014.

Departemaen Pendidikan Nasional (2001), Kamus Besar Bahasa Indonesia, Jakarta: Balai Pustaka.

Djaali (2013), Psikologi Pendidikan, Jakarta: Bumi Aksara.

Djamarah, Syaiful Bahri (2012), Psikologi Belajar, Cet. I; Jakarta: PT Rineka Cipta, 2012.

Endriani, Ani, Indikator Minat Belajar (2011), dalam aniendriani.blog.spot.com. diakses pada tanggal 10 Juni 2017.

Fauzi, Ahmad (2014), Psikologi Umum, Cet. II; Bandung: CV. Pustaka Setia.

Gie, The Liang (2014), Cara belajar yang efektif, Cet. I; Yogyakarta PUBIB.

Gie, The Liang (2014), Cara Belajar yang Efisien, Cet. I; Yogyakarta: Liberty.

Hamalik, Oemar (2013), Kurikulum dan Pembelajaran, Cet. II; PT. Bumi Aksara.

Iskandar (2012), Psikologi Pendidikan, Ciputat: Gaung Persada Press.

Jamaris, Martini (2014), Kesulitan Belajar: Perspektif, Asesmen, Dan Penanggulangannya Bagi Anak Usia Dini Dan Usia Sekolah, Bogor: Ghalia Indonesia.

Nashar (2014), Peranan Motivasi dan Kemampua awal dalam Kegiatan Pembelajaran, Jakarta: Delia Press. 
Poerbakawatja, Soeganda dan Harahap (2012), Ensiklopedia Pendidikan, Cet. III; Jakarta: Gunung Agung.

Poerwadarminta, W.J.S. (1976), Kamus Umum Bahasa Indonesia, Jakarta: Balai Pustaka.

Purwanto, Ngalim (2014), Psikologi Pendidikan, Cet. II; Bandung: PT. Remaja Rosdakarya.

Pusat Bahasa Departemen Pendidikan Nasional (2013), Kamus `Bahasa Indonesia Jakarta: Pusat Bahasa.

Santrock, John W. (2012), Live Span Developmen, Alih Bahasa: Achmad Chusairi, Perkembangan Masa Hidup, Edisi Kelima, Jilid 1-2, Jakarta: Penerbit Erlangga.

Sardiman, AM (2015), Interaksi dan Motivasi belajar Mengajar, Cet. IV; Jakarta: CV. Rajawali.

Sardiman, Arif (2004), Interaksi dan Motivasi Belajar Mengajar, Jakarta Raja Grasindo Persada.

Slameto (2013), Belajar dan Faktor-faktor yang Mempengaruhinya, Jakarta: Rineka Cipta.

Sobur, Alex (2013), Psikologi Umum Dalam Lintasan Sejarah, Cet. 1; Bandung: CV Pustaka Setia.

Sudjana, Nana (1987), Dasar-dasar Proses Belajar Mengajar, Bandung: Balai Pustaka.

Sujanto, Agus (2013), Psikologi Umum, Cet. VIl; Jakarta: Aksara Baru.

Sumanto (2014), Psikologi Umum, Cet. 1; Jakarta: PT. Buku Seru.

Sumanto, Wasti (2014), Psikologi Pendidikan, Jakarta: Bina Aksara.

Suryabrata, Sumadi (2012), Psikologi Pendidikan, Jakarta: CV. Rajawali.

Syah, Muhibbin (2013), Psikologi Pendidikan dengan Pendekatan Baru, Cet. I; Bandung: PT. Remaja Rosdakarya.

Uno, Hamzah B. (2014) Teori Motivasi dan Pengukurannya, Cet. XI; Jakarta: Bumi Aksara.

Usman, Moh. Uzer dan Lilis Setiawati (2012), Upaya Optimalisasi Kegiatan Belajar Mengajar, Bandung: PT. Remaja Rosda Karya.

Winkel, W.S. (2013), Psikolgi Pendidikan dan Evaluasi Belajar, Jakarta: Gramedia. 